\title{
Science process skills acquisition level among form two students in one district of Sabah
}

\author{
Nurfarah Dina Kahar and Siti Shamsiah Sani* \\ Sultan Idris Education University, Malaysia
}

Received: 27 September 2017; Accepted: 6 March 2018; Published: 4 June 2018

This research was conducted to identify the acquisition level of science process skills among Form 2 students in one of the districts of Sabah, Malaysia, and to investigate the difference between male and female students' acquisition levels of such skills. The survey study involved a sample of 269 students (134 female and 135 male) aged 14 to 15 years using the Science Process Skills Test (SPST) that consists of 35 items covering Basic Science Process Skills (BSPS) and the Integrated Science Process Skills (ISPS). The descriptive statistical results indicated that the science process skills for both male and female students were at a moderate level. The male and female students scored $47.28 \%$ and $49.89 \%$ respectively in the SPST. The independent t-test result revealed that there was no significant difference between male and female students' science process skills, although female students got better scores compared to male students with a p-value (0.684) that was more than 0.05 ( $p>0.05$ ). In conclusion, the acquisition of science process skills among students was at a moderate level for both genders despite the different teaching and learning approaches suggested by the Ministry of Education. This indicates the need for more attention being paid towards the teaching and learning activities that might enhance students' science process skills, and might direct future research in terms of factors that might affect students' performance in terms of such skills.

Keywords: Proficiency, basic science process skills, integrated science process skills, practical work, science investigation.

\section{Introduction}

The philosophy of science education is to nurture science and technology culture by focusing on the development of individual who are competitive, dynamic, robust and resilient and able to master scientific knowledge and technological competency' (Ministry of Education, 2015, p. vii). Based on this philosophy, it is clear that science education aims to produce a holistic individual. Such aims are not only focused on the development of a scientific and technologically literate citizen with competent scientific skills, the ability to cope with rapid change in science and technology, but also one who embraces noble values. The aim is also

\footnotetext{
${ }^{*}$ Email: siti_shamsiah@fsmt.upsi.edu.my
} 
to produce citizens that can manage nature knowledgeably and with responsibility for a better future.

In 2017, the Ministry of Education (MOE) in Malaysia launched a new science curriculum that is known as 'Dokumen Standard Kurikulum dan Pentaksiran-DSKP' (Standard Curriculum Document and Assessment) for science. The new curriculum is imposed on students aged between 13 and 15 years. They are studied at Form or Grade 1, Form 2 and Form 3. Bahagian Pembangunan Kurikulum (Curriculum Development Department) stated the main goal of the science education curriculum in Malaysia is to provide students with knowledge, science process skills as well as skills in the use of technology which enable them to solve problems and making decision in their everyday lives (Bahagian Pembangunan Kurikulum, 2011). There are a number of changes implemented in the new curriculum in terms of its content, learning standards, teaching approaches and assessment. Based on the new curriculum, most of these teaching approaches are based on the constructivism theory of learning that emphasizes the acquisition of knowledge as a result of the learner's own experiences (DSPK, 2016). One of teaching approaches that is highlighted by the MOE is practical work. Through practical work, students not only acquire scientific knowledge, but also scientific skills, as students have the opportunity to interact directly with the material to be studied in order to form new ideas (Yahya \& Amiruddin, 2008). Students have the opportunity to gain experiences in real situations (Seth \& Ezan, 2010). In practical work students are actively involved in manipulating objects and materials in order to solve problems. They may combine their existing knowledge with new information in order to build a new set of knowledge (Zainal, 2007). Besides developing knowledge and scientific skills, practical work promotes social interaction among students and teachers (Nelly, 2012). As a result, teaching and learning science becomes more meaningful, as it promotes knowledge, scientific skills, values, and interactions among students.

Another aspects that is highlighted in the new science curriculum is the development of scientific skills. These skills are important in the development of the concepts of science (Hen, 2011). Scientific skills can be divided into two categories - science process skills and manipulative skills (Bahagian Pembangunan Kurikulum, 2011). Science process skills refer to skills that are needed to process information around the students in order to find systematic answers, while manipulative skills relate to the student's ability when it comes to handling science equipment and materials (Ten, 2004). To ensure both aspects can be achieved, the MOE requires Science subjects to be taught five times a week for the equivalent of 200 minutes (3.5 hours) per week (Ministry of Education, 2014). Normally science lessons are divided into two slots involving practical work and studying science-related theories and facts (Lilia, 2013). This has becomes a norm as science subject is not merely focused on the acquisition of concepts and science-related theories in the classroom, but also emphasize the development of scientific skills (Abu Hassan \& Asmayati, 2014).

Through the new science curriculum, the level of student acquisition in terms of science process skills has become more profound. In the previous science curriculum, the MOE highlighted 12 science process skills in the form of observing, categorizing, making hypotheses, measuring and using numbers, making inferences, predicting, communicating, interpreting data, controlling variables, defining operations, and experimenting, as well as using time and space. In a previous science curriculum, there was no rubric or standard to indicate students' performance in each of these science process skills. However, in the new science curriculum the MOE has highlighted science process skills' standards by identifying different levels for each skill. The acquisition levels range from level 1 to level 4 . Table 1 shows the levels of each science process skill (Bahagian Pembangunan Kurikulum, 2012). 
Journal of Research, Policy \& Practice of Teachers \&

Teacher Education (ISSN 2232-0458/ e-ISSN 2550-1771)

Vol. 8, No. 1, June 2018, 32-44

Table 1. Level of science process skills

\begin{tabular}{cl}
\hline Level & Types of science process skills \\
\hline Level 1 & Observing, categorizing \\
Level 2 & $\begin{array}{l}\text { Estimating, formulating hypothesis, controlling the } \\
\text { variables, experimenting }\end{array}$ \\
Level 3 & $\begin{array}{l}\text { Comparing, inferring, measuring and using numbers, } \\
\text { using times and spaces } \\
\text { Level } 4\end{array}$ \\
\end{tabular}

Level 1 comprises observing, categorizing and predicting requiring students to use their five senses with regard to the occurrence or phenomenon found in their surroundings. Level 2 consists of estimating, formulating hypotheses, controlling variables as well as experimenting in order to enable students to engage their scientific knowledge when it comes to solving problems (Bahagian Pembangunan Kurikulum, 2011). Level 3 involves comparing, inferring, measuring and using numbers, as well as using time and space. This higher level aims to help students by acting as a guidance for them to find the solutions to phenomenon by the means of the use of creativity which may drive the problem-solving process. Last, but not least, the highest level of all (level 4) consists of interpreting data and arriving at conclusions. This level requires students to make use of critical thinking skills so as to give them a clue when it comes to summarizing the main cause and effect of the phenomenon under consideration by the end of the experiment.

Despite of the implementation of the new curriculum, the students are still exposed to low levels of inquiry such as confirmation and structured inquiry. Based on the practical work that is suggested in the textbook, the experiments that students perform in the laboratory are in the form of a "recipe" as stated by Hodson (1990). For example, students are required to follow the prescribed procedure to conduct an experiment to test the presence of starch. Therefore, students do not have an ample opportunity to explore and create their own understanding of the phenomenon (Che Nidzam, Halim \& Kamisah, 2010). All experimental procedures are given to the students through textbooks or practical workbooks. Students do not have the opportunity to engage directly in planning an investigation. They are only involved in recording the final results of the experiment in blank spaces provided in the practical workbook. As a result, they do not have the opportunity to develop basic science processes and integrated science process skills as a result of undertaking the experiment (Abu Hassan \& Asmayati, 2014).

Previous studies show that most teachers put less emphasis on students' science process skills, particularly in the case of integrated science process skills. Aloyah (2002) argued that some teachers plan activities for students which means that they only engage in observing the phenomenon produced by the teacher and write the answers in the practical book. These teachers do not engage students in hands-on activities but only allow them to observe the demonstration that is conducted by the teacher. Nor are students involved in planning the scientific investigation as all the instructions are provided in the practical book (Norsakimayuzie, 2008). Through such prescribed activities, students only have limited 
chances to practice integrated science process skills such as designing experiments, formulating hypotheses or interpreting data.

There are number of studies that examined students' science process skills acquisition level at lower or upper secondary school level. Researchers examined the science process skills acquisition level among students from different aspects such as genders, location, and academic achievement (Hazrulrizawati, 2007; Ong, 2010; Ong \& Bibi, 2013; Zainuddin, 2015). Most of the studies were conducted in Malaysian peninsula and the results could not be generalized to students in Eastern Malaysia particularly Sabah. Thus it is important to conduct a study to investigate the science process skills acquisition level among students at lower secondary school level particularly in Sabah. Beside that one of the aspects highlighted in Malaysia Education Blueprint 2013-2025 is an equal access to education (MOE, 2015). All children despite gender, socioeconomic, and location have equal chances to get the education. Science is one of core subjects that not only focused on conceptual knowledge but also science process skills. This subject is taken by students at all level despite their gender. Therefore it is crucial to examine to what extend male and female students have acquired science process skills based on new curriculum.

\section{Research objectives}

This study aims to investigate the following objectives:

I. Identify the science process skills acquisition level among Form 2 students in one district of Sabah according to gender.

II. Differentiate the science process skills acquisition level among Form 2 students in one district of Sabah according to gender.

\section{Research questions}

I. What is the science process skills acquisition level among Form 2 students in one district of Sabah according to gender?

II. Is there any significant difference in the science process skills acquisition level among Form 2 students in one district of Sabah according to gender?

\section{Research hypothesis}

$\mathrm{HO}_{1}$ : There is no significant difference in the science process skills acquisition level among Form 2 students in one district of Sabah according to gender.

\section{Literature review}

A number of studies have been carried out to investigate the acquisition of scientific process skills among students, both locally and internationally (Afif \& Majdi; Gokul \& Nirmala, 2014; Suhailah, 2006; Abu \& Rohana; 2003). In Malaysia, a number of researchers have conducted research related to science process skills (Abu Hassan \& Asmayati, 2014; Ong \& Junaidi, 2010; Zuraida, 2006, Abu \& Rohana, 2003). However, these studies only survey the level of acquisition of the three basic science process skills and the two integrated science process skills and do not focus on the overall science process skills. Studies which were conducted by Abu Hassan and Rohana (2003) as well as Abu Hassan and Asmayati (2014) only focused on certain science process skills such as hypothesising skills, interpreting data, predicting, identifying variables, making inferences and experimenting. Both studies were conducted in terms of chemistry students, with the use of questionnaires. They revealed that the acquisition 
of science process skills among students was at a moderate level. Abu Hassan and Asmayati (2014) suggested that students were unable to fully grasp science process skills as they were only exposed to prescribed activities from textbook or workbooks.

There are number of researchers who have attempted to compare the science process skills acquisition level of female and male students (Afif \& Majdi, 2015; Ergul, Simsekli, Caliz, Ozdilek, Gocmenacelebi \& Sanli, 2011; Gokul \& Nirmala, 2014). Similarly, those studies only focused on certain science process skills such as observing, classifying, measuring and using numbers, predicting, communicating, controlling variables, hypothesizing, experimenting and interpreting data. Although the studies were carried out in different parts of the world, the findings suggested that female and male students' science process skills acquisition level are at a moderate level. There were no significant differences between those two groups of students in any of the studies.

The acquisition of scientific skills is very important to ensure students are able to fully grasp scientific knowledge. A study conducted by Rafei (2006) demonstrated that scientific skills and scientific knowledge are correlated to each other. He found out that students who have good scientific skills are also have good scientific knowledge. The results indicate that students who are in possession of scientific skills do not to rely only on their awareness of scientific concepts to develop their knowledge skills (Aydogdu \& Ergin, 2008). A number of studies have suggested different ways to improve students' science process skills. Ergul et al. (2011) suggested that the use of $21^{\text {st }}$ century learning styles can enhance science process skills and improve attitudes toward science on the part of students. Thus teachers should engage students with the use of appropriate activities such as inquiry learning as a result of which students are actively involved in finding the solution for problems that they are faced with.

\section{Methodology}

\section{Research design}

A quantitative approach involving surveys was implemented in the study. A quantitative approach is an investigation that emphasizes investigation that is to be interpreted through data analysis (Chua, 2006). Such an approach was used because it can view the students' overall science process skills in a particularly systematic and clear way as a result of the survey carried out by the researcher. In addition, a survey research design was chosen as the study aimed to identify the science process skills acquisition level of form 2 students in one district in Sabah. The design of this study was chosen to help the researcher to analyze the data such that the findings can be generalized to the whole population. The survey research design is appropriate as the total student population is too large (Babbie, 2004). Therefore, this survey design was chosen because it is considered to be most appropriate one when it comes to studying the science process skills acquisition level among Form 2 students of secondary schools in one district in Sabah state.

\section{Participants}

This study was carried out to identify the acquisition level of science process skills on the part of Form 2 female and male students in one of the districts of Sabah state. Form 2 is referred students who study at lower secondary school level or junior high school. Their ages are between 14 and 15 years old. The total population of form 2 students in the district was 943 students from six schools. However, only 269 students were involved in this study as suggested by Krejcie and Morgan (1971). Diagram 1 shows the calculation of the sample used on this study for each school involved in one district of Sabah state. 
$=\frac{\text { Number of sampling using Krejcie and Morgan }}{\text { Population study }} \times$ Total of Form 2 students for one district

Diagram 1. Calculation of sample for each schools

By using the formula noted above, the sample used in this study was taken by dividing population from different stratum (schools) which was then recombine together so that the sample study used are quite accurate (James, 1971). The size of the sample from each school is identified through stratified random sampling. Table 2 shows the size of the sample from each school.

Table 2. Sampling calculation using stratified random sampling techniques.

\begin{tabular}{cccc}
\hline School & $\begin{array}{c}\text { Number of students } \\
\text { from each school }\end{array}$ & $\begin{array}{c}\text { Number of students according } \\
\text { to gender }\end{array}$ & \\
\cline { 3 - 4 } & & Male & Female \\
\hline A & 47 & 23 & 24 \\
B & 45 & 22 & 23 \\
C & 49 & 25 & 24 \\
D & 47 & 24 & 23 \\
E & 54 & 28 & 26 \\
F & 27 & 13 & 14 \\
Total & 269 & 135 & 134 \\
\hline
\end{tabular}

\section{Instruments}

In the study, a questionnaire is used as the instrument for data collection. The questionnaire is chosen for data collection in order to investigate the Form 2 students' science process skills acquisition level for one district in Sabah state. The Science Process Skills Evaluation Test (SPST) used in the study, as proposed by Ong and Junaidi (2013), was used to measure the students' science process skills acquisition levels. The questionnaire comprised of 35 items which cover both Basic Science Process Skills (BSPS) and Integrated Science Process Skills (ISPS). Table 3 shows the total item for each science process skill. 
Journal of Research, Policy \& Practice of Teachers \&

Teacher Education (ISSN 2232-0458/ e-ISSN 2550-1771)

Vol. 8, No. 1, June 2018, 32-44

Table 3. Total item for each science process skills

\begin{tabular}{|c|c|c|}
\hline Science process skills & Type of skills & No of item \\
\hline \multirow{7}{*}{$\begin{array}{l}\text { Basic science process } \\
\text { skills }\end{array}$} & Observing & 3 \\
\hline & Classifying & 3 \\
\hline & Measuring and using number & 3 \\
\hline & Making inferences & 3 \\
\hline & Estimating & 3 \\
\hline & Communicating & 3 \\
\hline & Using times and spaces & 2 \\
\hline \multirow{6}{*}{$\begin{array}{l}\text { Integrated } \\
\text { process skills }\end{array}$} & Making hypothesis & 3 \\
\hline & Controlling variables & 3 \\
\hline & Interpreting data & 3 \\
\hline & Experimenting & 3 \\
\hline & Defining the operation & 3 \\
\hline & Total item & 35 \\
\hline
\end{tabular}

Before the study was conducted, researchers sought for approval from Education Planning and Research Department (EPRD), State Education Department of Sabah, and schools in Sabah. In the main study 269 questionnaires were distributed to six schools in one districts of Sabah. The results of main study will be discussed in the following section.

\section{Results}

A normality test is conducted to enable the study findings to be adopted. In order to achieve the basic assumptions of statistical procedures, the data to be collected should be normalized. As such, the normality test is one of the prerequisites for most inferential statistical methods (Anderson, Babin, Black \& Hair, 2009). There are various types of test to determine the normality of the data. Among them are histograms, stem-leaf, probability of Q-Q plot, skewness and kurtosis (Pallant, 2011). The test used is kurtosis skewness for conducting normalized tests. All the variables set in this study, namely kurtosis and skewness values, are between -2 and +2 . According to George and Mallery (2005), the relative value is a normal and acceptable distribution of a particular study in the field of education and social science. 
Table 4 shows the distribution of skewness and kurtosis values for each variable used in this study.

Table 4. Distribution of skewness and kurtosis values for each variable

\begin{tabular}{lll}
\hline Gender & Skewness & Kurtosis \\
\hline Male & .254 & -1.033 \\
Female & .321 & -1.250 \\
\hline
\end{tabular}

The results are divided into two parts. The first part of the results discusses the female and male students' responses in the SPST questionnaire. This part aimed to answer the first and second research objectives. The second part of the results were intended to answer the third research objective which is to differentiate between the female and male students' science process skill acquisition levels. Based on the responses, it demonstrates that, in general, the science process skills acquisition levels for both male and female students are at a moderate level. However, students' performances for each basic and integrated science process skill varied between female and male students. It shows that male and female students achieve a mean score ranging from $49 \%$ to $74 \%$ for basic science process skills. However, the score plummets to $27 \%$ for integrated science process skills for both groups of students. Table 5 offers a summary of the science process skills acquisition level for both male and female students.

Table 5. The mean value of male and female student score in Science Process Skills Test (SPST) questionnaire.

\begin{tabular}{|c|c|c|c|c|c|}
\hline \multirow[t]{2}{*}{ SPS aspect } & \multirow{2}{*}{$\begin{array}{l}\text { No } \\
\text { item }\end{array}$} & \multicolumn{2}{|l|}{ Male } & \multicolumn{2}{|c|}{ Female } \\
\hline & & $\%$ & Level & $\%$ & Level \\
\hline Observing & 3 & 66.67 & Good & 71.64 & Good \\
\hline Classifying & 3 & 63.70 & Good & 72.63 & Good \\
\hline $\begin{array}{l}\text { Measuring and } \\
\text { using numbers }\end{array}$ & 3 & 52.35 & Moderate & 54.48 & Moderate \\
\hline Making inferences & 3 & 74.07 & Good & 74.63 & Good \\
\hline Predicting & 3 & 53.58 & Moderate & 51.00 & Moderate \\
\hline Communicating & 3 & 46.17 & Moderate & 49.25 & Moderate \\
\hline Interpreting data & 3 & 37.78 & Poor & 36.82 & Poor \\
\hline
\end{tabular}




\begin{tabular}{|c|c|c|c|c|c|}
\hline $\begin{array}{l}\text { formulating } \\
\text { hypothesis }\end{array}$ & 3 & 50.12 & Moderate & 55.47 & Moderate \\
\hline Controlling variable & 3 & 29.88 & Very Poor & 31.34 & Poor \\
\hline Defining operation & 3 & 38.03 & Poor & 38.31 & Poor \\
\hline Experimenting & 3 & 27.65 & Very Poor & 27.65 & Very Poor \\
\hline $\begin{array}{l}\text { Using times and } \\
\text { space }\end{array}$ & 2 & 27.41 & Very Poor & 35.45 & Poor \\
\hline Total & 35 & 47.28 & Moderate & 49.89 & Moderate \\
\hline
\end{tabular}

Female students' performance with regard to observing, categorizing, and making inferences were at a good level as the mean scores ranged between $71.64 \%$ and $74.63 \%$. Similarly the male students were also good in these skills as they scored between $63.70 \%$ and $74.07 \%$. Hence, both male and female student's science process skills acquisition were at a moderate level for the following skills: measuring and using numbers, predicting, communicating, and formulating hypothesis. The mean scores ranged from $51.00 \%$ to $55.47 \%$ and $50.12 \%$ to $53.58 \%$ for female and male students respectively. The female students' performance was at a poor level in terms of interpreting data, controlling variables, defining operations, and using time and space, as their scores ranged from $31.34 \%$ to $38.31 \%$. On the other hand, male students scored very poorly in controlling variables as well as in using time and space, as they scored $29.88 \%$ and $27.41 \%$ respectively. They also scored poorly in interpreting data $(37.78 \%)$ and defining operations $(38.03 \%)$. Nonetheless, both female and male students scored very poorly in experimenting, as they both obtained similar mean scores of $27.65 \%$. It clearly shows that both group of students are still struggling to master the integrated science process skills, but can do very well in basic science process skills.

The second part of the results are focused on the third research objective that aimed to compare the level of science process skills acquisition between female and male students in one of the districts in Sabah state. The independent t-test was used to compare female and male students' mean scores in the science process skills questionnaire test (independent sample t-test). Table 6 shows the different mean score of female and male students in the science process skills test.

Table 6. Female and male students' mean score in terms of science process skills.

\begin{tabular}{llllll}
\hline $\begin{array}{l}\text { Ge } \\
\text { nde }\end{array}$ & N & $M$ & $S D$ & $t$ & $\begin{array}{l}\text { signifi } \\
\text { cant } \\
\text { r }\end{array}$ \\
\hline Bo & 13 & 47.2 & 16.5 & .3 & .684 \\
ys & 5 & 8 & 4 & 99 & \\
\hline
\end{tabular}

*Note $: M=$ mean, $S D=$ standard deviation, significant level, $p=0.05$ 


\begin{tabular}{llll}
\hline Gir & 13 & 49.8 & 15.6 \\
ls & 4 & 9 & 4
\end{tabular}

The independent $\mathrm{t}$-test results showed that there is not a significant different between female student $(M=49.89$, and $\mathrm{SD}=15.64)$ and male student $(\mathrm{M}=47.28$, and $\mathrm{SD}=16.54)$ scores in the SPST test-t $(269)=.399, \mathrm{p}=.684, \mathrm{p}>0.05$. The results suggest that both female and male student acquisition levels in terms of science process skills are similar. In general both groups of students showed a moderate performance in terms of science process skills.

\section{Discussion}

The acquisition of the science process skills level of both male and female students was at a moderate level - male (47.28\%) and female (49.89\%). Based on Ong and Al Junaidi's study (2013), male science process skills was lower (49.92\%) compared to the female science process skills (50.74\%), both at a moderate level. According to Hofstein and Lunetta (2004), students' scientific learning resulting from the use of recipe books in lab activities only helped to improve their basic science process skills but not their integrated science process skills. Therefore, students were unable to develop their scientific process skills. This was due to their science teachers focusing more on the efforts to finish the syllabus without considering the level of inquiry engaged in during science learning (Jemaah Nazir, 1995).

The results show that the mean percentage of male $(66.67 \%)$ and female $(71.64 \%)$ students in terms of observing skills were good. The findings were similar to those of Hazrulrizawati (2007). The emphasis on observing science process skills actually started from someone's desire to learn science during preschool. It is actually the most basic aspect of science process skills, and is often used in science learning (Ango, 2002). Students begin a lesson through observation (Zainudin, 2015). Therefore, this skill is important for students to help them understand the phenomenon they are considering. Good observations skills also help students to create essential traits based on their observation using their five senses. From there, students can learn more by doing and watching it alone (Millar, 2004).

Then, statistical tests using the independent $\mathrm{t}$ - test showed that there was no significant difference between the male and female student groups. The data also found out that there was no significant difference, with a value of $p=.684$. Both groups in this sample demonstrated the same level of achievement, namely moderate achievement in terms of their science process skills level. Ong and Al-Junaidi (2013) found that there was a significant difference between the basic and integrated science process skills with regard to male and female students which was statistically insignificant with the overall score of SPS ( $p=0.14$ > 0.05). This finding was parallel with Ong and Shamalah (2014) who stated that there was no gender difference in terms of students' acquisition in their science process skills. This is because male and female students in Malaysia receive a holistic education, regardless of their gender. The majority of schooling in Malaysia is heterogeneous, in that male and female students study at the same institution, in the same class. The results show that the students had a low level of science process skills. This is because students are still not aware of the importance of mastering SPS aspects when it comes to mastering science subjects (Rafei, 2006). The findings show that female students still have not mastered basic science process skills such as space and time skills (31.43\%) while for male students, mastery of control variables is still at very low levels $(30.61 \%)$.

\section{Conclusion}

The results of this study provide the latest information to the Ministry of Education and the District Education Office in one district of Sabah state regarding the level of science process 
skills among Form 2 students. The data obtained in this study can also be used as a reference for the Ministry to facilitate efforts to increase awareness of the importance of science process skills among students, especially in Sabah state. In order to improve students' science process skills the use of 'recipe books' with regard to practical work in conducting experiments should be minimized. Students should be provided with more opportunities to experience more openended practical work. The results are implied to form 2 students in one district of Sabah only. A wider sample size that take into consideration students from different districts is required to generalize the results to all students in Sabah.

\section{References}

Abu Hassan, K., \& Asmayati, Y. (2014). Perlaksanaan Kurikulum Sains KBSM Sekolah Menengah di Negeri Perak: Ke manakah arah tujunya? Journal of Applied Research in Education, 6785.

Abu Hassan, K., \& Rohana, H. (2003). Tahap penguasaan kemahiran proses sains dan hubungannya dengan pencapaian Kimia di kalangan pelajar Tingkatan Empat daerah Johor Bahru. Jurnal Fakulti Sains dan Matematik, 4 (4), 1-15.

Afif, H., \& Majdi, R. (2015). Science Process Skills and attitudes toward Science among Palestinian Secondary School students. World Journal of Education., 5 (1), 13-20.

Anderson, R., Babin, B., Black, W., \& Hair, J. (2009). Multivariate Data Analysis (5th ed.). Upper Saddle River: Prentice-Hall, 34-57.

Anggarita, M. P., Ketut, I. M., \& Nuriman. (2011). Model pembelajaran inkuiri bebas (free inquiry) dalam pembelajaran multirepresentasi fisika di MAN 2 JEMBER. Jurnal Pendidikan, 6-59.

Ango, M. (2002). Mastery of science process skills and their effective use in the nigerian context. International Journal of Educology, 16 (1), 11-30.

Babbie, E. (2004). The practice of social research (9th ed.). Belmont, California, United State of America: Wadsworth Publishing Company.4(2). 23-28.

Bahagian Pusat Kurikulum. (2011). Kurikulum Bersepadu Sekolah Menengah. KBSM. Transformasi Pendidikan Negara. Kementerian Pendidikan Malaysia, Kuala Lumpur: Pusat Pembangunan Kurikulum. 5 - 20.

Che Nidzam., Che. A., Lilia. H., \& Kamisah. O. (2010). Hubungan ramalan persekitaran pembelajaran makmal Sains dengan tahap kepuasan pelajar. Jurnal Pendidikan Malaysia , 4 (2), 19-30.

Chua, Y. (2006). Kaedah dan statistik penyelidikan kaedah penyelidikan buku 1 (4th ed.). Shah Alam, Selangor : McGraw-Hill (Malaysia) Sdn. Bhd. 43-67.

Duschl, R., \& Osborne, J. (2002). Supporting and promoting argumentation discourse in science education. Studies in Science Education, 39-72.

Ergul, R., Simsekli, Y., Caliz, S., Ozdilek, Z., Gocmencelebi, S., \& Sanli, M. (2011). The effect of inquiry-based Science teaching on elementary school students' science process skills and science attitudes. Bulgarian Journal of Science and Education Policy (BJSEP) , 6 (3), 4868.

George, D., \& Mallery, P. (2005). SPSS for Windows: Step by Step: A Simple Guide and Reference 12.0 Update. (5th ed.). Boston: Pearson Education. 24-45.

Gokul, R., \& Nirmala, S. (2014). Science process skills and achievement in science among high school student. Journal of Science Education , 23 (9), 2437-2443.

Hazrulrizawati, A. (2007). Perbandingan penguasaan kemahiran proses sains dan cara penglibatan pelajar dalam kaedah amali tradisional dengan kaedah Makmal Mikro Komputer. Tesis Sarjana Muda: Universiti Teknologi Malaysia. Jurnal Sains dan Teknologi, 3 (4), 7-24.

Hofstein, A., \& Lunetta, V. (2004). The laboratory in science education: Foundation for the $21^{\text {st }}$ century. Science Education, 8 (2), 34-39.

James, A. (1971). Elementary Survey Analysis. (2nd ed.). Belmont: Wadsworth Publication Company. 69-89. 
Jemaah Nazir Sekolah. (1995). Kajian mengenai persediaan dan pengelolaan kelas. 4 (33). 3-25.

Kementerian Pendidikan Malaysia. (2012). Dasar Pendidikan Kebangsaan. Transformasi Pendidikan Negara. Kuala Lumpur: Pusat Perkembangan Kurikulum. 30-45.

Kementerian Pendidikan Malaysia. (2012). Kurikulum Bersepadu Sekolah Menengah. Huraian Sukatan Pelajaran Pendidikan Sains Tingkatan 2. Kuala Lumpur: Pusat Perkembangan Kurikulum. 3-10.

Kementerian Pendidikan Malaysia. (2011). Laporan Awal Pelan Pembangunan Pendidikan Malaysia 2013-2025. Kuala Lumpur: Pusat Perkembangan Kurikulum.23-46.

Krejcie, R., \& Morgan, D. (1970). Determining sample size for research activities. Educational and psychological measurement. Journal of Research, 30 (4), 607-610.

Lilia, H. (2013). Pembentukan masyarakat literasi Sains dalam Pendidikan Sains. Penang, Malaysia: USM Publisher. 3-68.

Millar, R. (2004, March 23). The role of practical work in the teaching and learning science. Paper presented at meeting: High school science laboratories: Role and vision. National Academy of Sciences. 32-55.

Ministry of Education. (2015). Executive Summary Malaysia Education Blueprint 2013-2025 (Preschool To Post-Secondary Education). Kuala Lumpur, Selangor. 1-10.

Nelly, E. F. (2012). Kesan Pembelajaran berasaskan kaedah Inkuiri bagi subjek Matematik. Jurnal Matematik, 24-39.

Noor Akma, T. (2007). Pendekatan inkuiri dalam pengajaran Biologi secara eksperimen. Universiti Kebangsaan Malaysia. Jurnal Pendidikan , 30-49.

Nor Sakimayuzie, A. (2008). Tahap kefahaman kemahiran meramal dan mengawal pemboleh ubah dalam kalangan pelajar tahun dua pendidikan fizik. Tesis Ijazah Sarjana Muda. Universiti Sains Malaysia. 32-54.

Ong, E., \& Bibi, O. (2013). Penguasaan kemahiran proses sains asas dalam kalangan murid sekolah rendah di Selangor berdasarkan jantina, lokasi sekolah dan aras tahun. Jurnal Pendidikan Sains dan Matematik Malaysia., 3 (2), 77-89.

Ong, E., \& Mohd Al Junaidi, M. (2013). Pembinaan dan penentusahan instrumen kemahiran proses sains untuk sekolah menengah. Jurnal Teknologi, 66 (1), 7-20.

Ong, T., \& Shamalah, O. (2014). Penguasaan kemahiran proses sains asas dalam kalangan murid india di beberapa buah sekolah rendah di Perak. Jurnal Fakulti Sains dan Matematik, 4 (1), 159-169.

Pallant, J. (2011, September 5). The development and validation of the test of basic process skills. Paper presented at the annual meeting of the National Association for Research in Science Teaching, French Lick, IN. 2-16.

Pelan Induk Pembangunan Pendidikan. (2006). Edisi Pelancaran. Kementerian Pelajaran Malaysia. $5-45$.

Pusat Perkembangan Kurikulum. (2002). Kurikulum Bersepadu Sekolah Menengah. KBSM. Huraian Sukatan Pelajaran Tingkatan Empat Kementerian Pendidikan Malaysia, Kuala Lumpur: Pusat Perkembangan Kurikulum. 4-18.

Rafei Sharif. (2006). Keberkesanan guru sains mengimplimentasikan kemahiran proses sains sepadu dalam pelaksanaan Kurikulum Sains KBSM tingkatan dua: Kajian kes di daerah Hilir Perak. Journal of Science and Mathematics Educational, Volume 3 Sept 2011, Pages 119/ISSN: 2231-7368.

Seth, S., \& Ezan Hazuriah, A. (2010). Tahap pencapaian kemahiran proses sains dalam matapelajaran Fizik di kalangan pelajar sekolah menengah daerah Kluang. Jurnal Pendidikan, 1-9.

Science Textbook Form 2 (2010). Kementerian Pendidikan Malaysia. muka surat 20 - 25.

Siti Aloyah, A. (2002). Penilaian pelaksanaan program PEKA Biologi. Universiti Kebangsaan Malaysia. Jurnal Pendidikan , 24-37. 
Ten, O. T. (2004). Tahap penguasaan kemahiran proses sains bagi kemahiran membuat hipotesis, mengawal pemboleh ubah, mentafsir maklumat dan mendefinisi secara operasi di kalangan pelajar tingkatan empat di daerah Kuala Terengganu, Terengganu. Tesis Ijazah Sarjana Muda. Universiti Malaysia Terengganu. 13-26.

Umar, I., \& Maswan, S. (2006). Aplikasi pendekatan Inkuiri dalam persekitaran pembelajaran berasaskan web. Jurnal Sains dan Teknologi, 4 (2), 5-16.

Yahya, B., \& Amiruddin, Y. (2008). Pendekatan pembelajaran secara konstruktivisme dalam kalangan guru-guru teknikal bagi matapelajaran teknik. Jurnal Fakulti Teknikal, 34-47.

Zainudin, B. A. (2015). Analisis kemahiran proses Sains, kemahiran manipulatif dan kecekapan penggunaan makmal dalam kalangan pelajar tingkatan empat. Tesis Sarjana Muda, Universiti Pendidikan Sultan Idris. 4-100. 